\title{
Corrosion of Water Pipes: a Comprehensive Study of Deposits
}

\author{
Vikas Chawla $^{\mathrm{a}}$, Prema G. Gurbuxani ${ }^{\mathrm{b} *}$ and G.R. Bhagure ${ }^{\mathrm{c}}$ \\ ${ }^{\mathrm{a}}$ Department of Mechanical Engineering, B.M.S.C.E Muktsar-152026, Punjab, India \\ ${ }^{\mathrm{b}}$ Chemistry Department, Smt. C. H. M. College, Ulhasnagar-421003, India \\ ${ }^{\mathrm{c} C h e m i s t r y ~ D e p a r t m e n t, ~ D n y a n a s a d h a n a ~ C o l l e g e, ~ T h a n e-400604, ~ I n d i a . ~}$ \\ *Corresponding author: gurprema@gmail.com
}

\begin{abstract}
S
Corrosion scales play an important role in modifying water quality in drinking water distribution systems. The corrosion scales from old water pipe lines were analyzed for their structure and composition. This paper presents the results of comprehensive study of deposits found in water distribution system of Ulhasnagar city of Maharashtra, India. Scales were investigated by XRD, FTIR, SEM and ED's analytical techniques. It was found that goethite, magnetite, lepidocrocite, hematite and Akaganite were identified as the primary constituents of brown deposits. The corrosion scales had a shell-like, enveloping layer, covering porous deposits of iron oxide phases. Our studies were able to identify important constituents of three different pipes of water distribution systems. Akaganite was found to be present in chloride environment. Along with iron hydroxide phases it was found that corrosion product also contain some organic matter which may be due to adsorption of biofilm on the surface of pipe. Further studies are needed to establish the role of corrosion scales in the mechanism of iron release from corroded pipes.
\end{abstract}

Key words: corrosion, water distribution system, brown deposits, iron oxides, bio-film.

\section{INTRODUCTION}


The water distribution system is key public health battlefield of the $21^{\text {st }}$ century. Iron and steel pipes have been used in water distribution systems for over five centuries. The water distribution network cannot be considered as inert system but a reactor interacting with the interior aqueous environments. During interaction the formation of unwanted deposits takes place [1]. The main source of deposit are particulate matter transported by water, dissolved oxygen, microbial activity, chlorides, sulphates and physicochemical reactions both at the pipe wall interface and within the water bulk [1-5]. Most water distribution systems have build up of iron corrosion products inside the iron pipes. Corrosion scale /deposits not only restrict the flow of water [6] but also degrade the quality of water. The scales are porous deposits that are comprised of iron hydroxide phases. Some ways in which corrosion scales can adversely affect the water quality in drinking water distribution pipes are 1) As a source of iron which then released into water can result in red water or which may change colour, odour and taste, 2) as source of high demand for dissolved oxygen and chlorine, 3) as an excellent breeding ground for microbes and, 4) adsorption and accumulation of substances such as arsenic [9-12] which when released on modification of water quality. Ionic species coming either from natural source or from pipe scales have been found to be probable cause of public health problems [13]. Additionally deposit formation may drastically reduce the hydraulic capacity of pipelines due to formation of tubercles [14].

Many research workers recently studied the composition of deposits in potable water system indicates that minerals, organic matter and biomass are the main constituents of drinking water deposits. Morphology and composition of corrosion products formed on the internal walls of ferrous pipe lines have also been studied revealing a strong influence of water quality on the characterization of deposit material and a direct correlation between composition of deposits and the bacterial species found [2]. Extensive public survey in the Ulhasnagar city of Maharashtra, India, reveals that lack of water through pipe, odour and colour of the water are not in the permissible limit. Therefore comprehensive study has been carried out to understand the consequences. Three pipe samples which forms a part of water distribution system in the city has been considered as sample for the study.

These Pipe samples were studied to characterize the physical properties and chemical compositions of corrosion scales using several analytical techniques such as XRD, FTIR, SEM and EDS. Both organic and inorganic matter was found to make part of the deposit. The compounds forming the deposits are reported.

\section{MATERIAL AND METHODS}

The infrastructure studied forms a part of Ulhasnagar Municipal Corporation. The pipe line was installed in the year 1952 to carry drinking water from Water treatment plants to Distribution storage tank. These pipe samples were labeled as big pipe, medium pipe and small pipes 
according to their size. These pipes were made from cast iron and the elemental chemical composition of pipes lines provided by Municipal Water supply department is presented in the Table-1. Corrosion products were removed from the inner surface of pipes by 600 grit paper and dried for 48 hours at $40{ }^{\circ} \mathrm{C}$. Then corrosion products were grinded using an agitate Mortar until approximately 98\% passed a no.325 mesh. Tools and techniques were XRD, FTIR and SEM and EDS.

Table-1: Elemental Chemical Composition (\%age) of Pipe Sample

\begin{tabular}{|c|c|c|c|c|c|c|c|}
\hline Element & Fe & Mn & Si & S & C & Mg & P \\
\hline $\begin{array}{c}\text { \% of } \\
\text { Element }\end{array}$ & 94 & $0.10-0.90$ & $2.00-3.00$ & $\begin{array}{c}0.03 \\
\text { Max. }\end{array}$ & $3.00-4.00$ & $0.030-0.080$ & 0.10 Max. \\
\hline
\end{tabular}

\section{RESULTS AND DISCUSSION}

\subsection{Big Pipe Sample}

The EDS measurement on powder sample ( brown deposit) from the big pipe identified that iron was the major component element of the scales besides carbon and oxygen.EDS analysis showed that iron was present $30.29 \%$ (atomic percent), Carbon at 8.86\%, oxygen at 59.99\%, while trace amount of other element such as Aluminium, Silicon, and Chlorine (See Table-2). The corrosion products are analysed by XRD and the results are shown in Fig.1.Goethite, $\alpha-\mathrm{FeOOH}$, $\mathrm{Fe}_{2} \mathrm{O}_{3} \cdot \mathrm{H}_{2} \mathrm{O}$ (Hydrated ferric oxide), hemitite $\alpha-\mathrm{Fe}_{2} \mathrm{O}_{3}$. Magnetite, $\mathrm{Fe}_{3} \mathrm{O}_{4}$ and lepidocrcocite, $\mathrm{Y}-$ $\mathrm{FeOOH}, \mathrm{FeO}_{3} \cdot \mathrm{H}_{2} \mathrm{O}$ ( hydrated ferric oxide).

Table-2: Most typical Values of brown deposits of Big Pipe Sample Obtained from EDS Analysis.

\begin{tabular}{|c|c|c|c|c|c|c|c|c|}
\hline Element & C & O & Al & Si & Cl & Fe & Zr & Total \\
\hline Weight \% & 3.76 & 34.11 & 0.15 & 0.29 & 1.16 & 60.52 & -- & 100 \\
\hline Atomic \% & 8.86 & 59.59 & 0.16 & 0.28 & 0.92 & 30.29 & -- & 100 \\
\hline
\end{tabular}



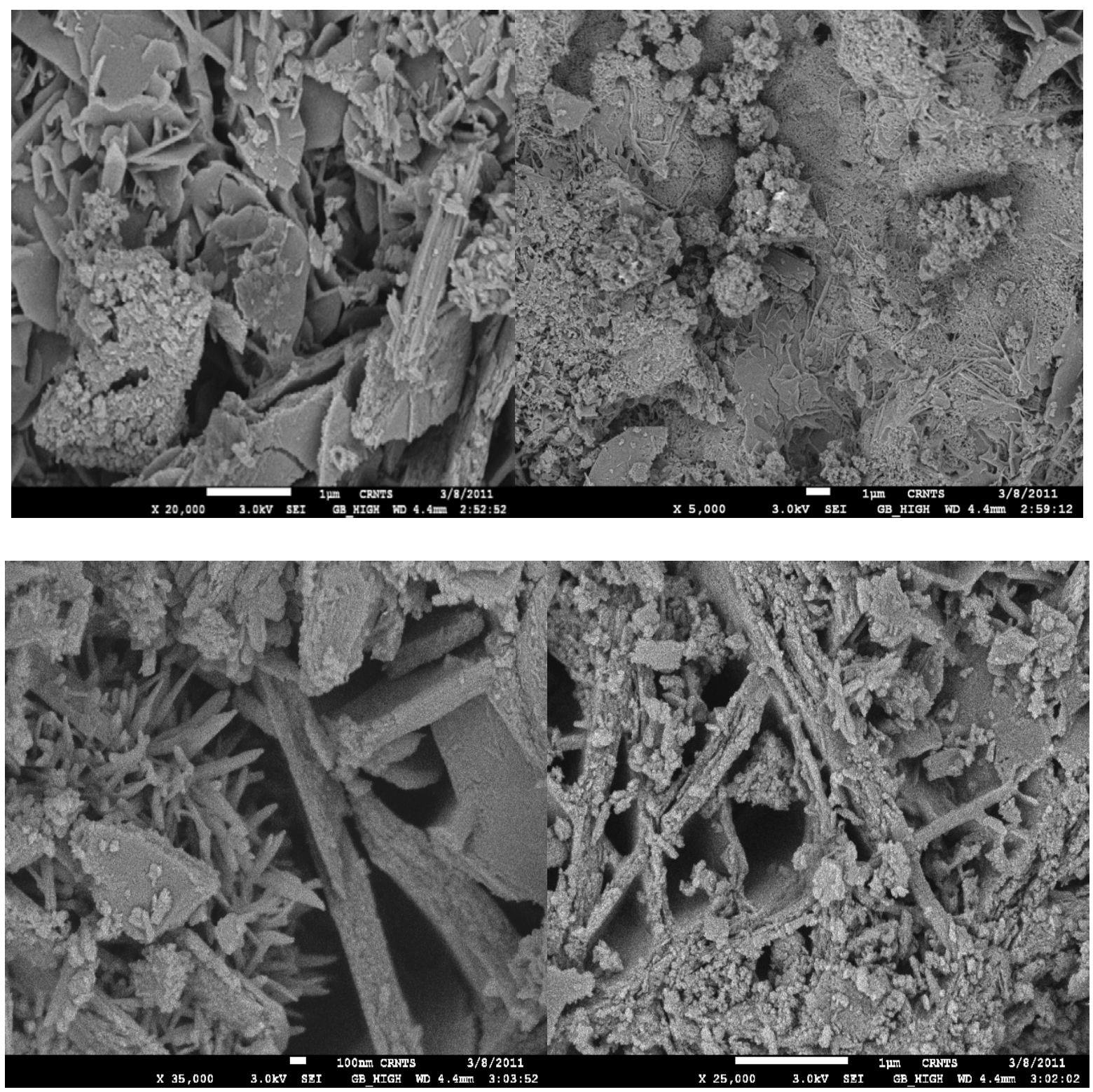

Fig.1: SEM Morphology of Big Pipe

It is confirmed from XRD Spectrum of big pipe sample (Fig.2) that the corrosion product mainly consist of Geothite; further result of XRD analysis shows that brown deposits reveal important variations according to colour intensity ; dark deposits appear to be amorphous and the lighter brown deposit contain crystalline compounds.Quartz as the main constituent mixed with an aluminium silicate hydroxide,most probably Kaoline.Similar compounds in potable water system were reported by many research workers[16,25]'The SEM mophology of big pipe sample (Fig.1) shows that goethite was stallactite -like on the surface of iron pipe .The grain of goethite was tiny and needle shape since it formed in the intial corrosion stages on the iron surface.The tubercle deposits formed in water system showed mainly the presence of Goethite and Magnetite with minor amount of Lepidocrocite (Fig.2). 


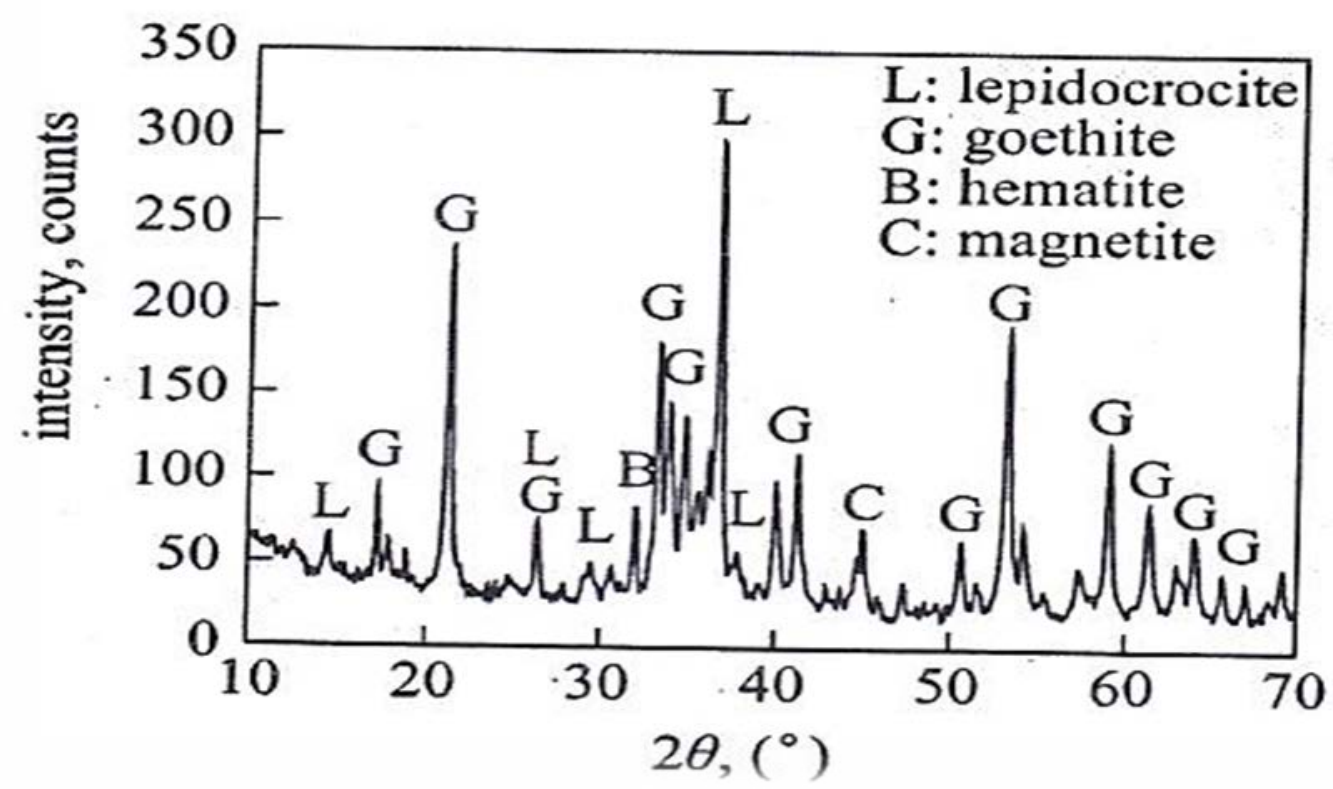

Fig.2.XRD Spectrum of Corrosion Product of Big Pipe Sample.

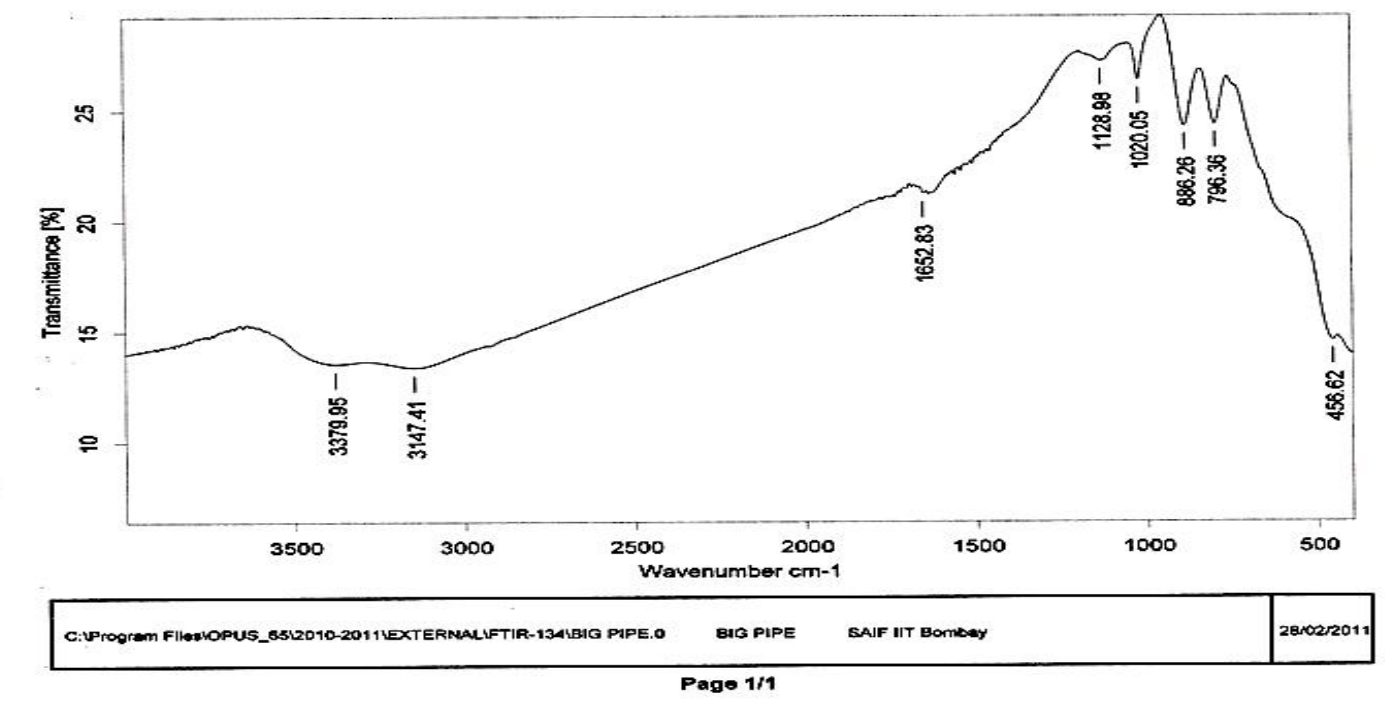

Fig.3: FTIR Spectrum of Big Pipe

Figure-3 shows the FTIR Spectrum of the Big pipe with a peak at $3380 \mathrm{~cm}^{-1}$ indicating presence of aluminosilicate ,Vibrationof amide species at $1653 \mathrm{~cm}^{-1}$ indicating the presence of biological material in the sample, similar obseravation was also reported by L.I.Sily and et.al. [26] and V.Guatheier and et.al. [27]. Another peak at $3147 \mathrm{~cm}^{-1}$ indicates the presence of aromatic group,Complex silicate [19] containing water or hydroxide groups seen at $1129 \mathrm{~cm}^{-1}$ and at 547 $\mathrm{cm}^{-1}$. Peaks at $1020 \mathrm{~cm}^{-1}$ and at $887 \mathrm{~cm}^{-1}$ indicates the prescence of Lepidocrocite and 
goethite [19]. Peak at $797 \mathrm{~cm}^{-1}$ indicates the presence of C-C vibrations and C-Cl vibrations. Similarly peak at $547 \mathrm{~cm}^{-1}$ indicates the presence of methyl group attached to silicon in silicate (Table-3).

Table-3: Result of the analysis of the IR Spectra of Big pipe Sample:

\begin{tabular}{|c|c|c|c|}
\hline $\begin{array}{c}\text { Sample } \\
\text { (Spectrum } \\
\text { ) }\end{array}$ & $\begin{array}{c}\text { Absorption } \\
\text { Frequency }\left(\mathrm{cm}^{-1}\right)\end{array}$ & $\begin{array}{c}\text { Related Compounds, Groups or } \\
\text { Vibration }\end{array}$ & References \\
\hline \multirow{8}{*}{ Big Pipe } & 3380 & Aluminosilicate & 19 \\
\hline & 3147 & $\mathrm{C}-\mathrm{H}$ aromatic & 19 \\
\hline & 1653 & $\mathrm{C}=\mathrm{C}$, Vibration of amide Species & 19 \\
\hline & 1129,547 & $\begin{array}{l}\text { Complex Silicate containing Water or } \\
\text { Hydroxide group Vibration. }\end{array}$ & 19 \\
\hline & 1020 & Lepidocrocite & 19 \\
\hline & 887 & Goethite & 19 \\
\hline & 797 & C-C Vibration, and C-Cl & 20 \\
\hline & 547 & $\begin{array}{l}\text { Presence of methyl group attached to } \\
\text { silicon in silicate }\end{array}$ & 19 \\
\hline
\end{tabular}

According to many research workers on the corrosion of iron water pipes and iron objects [17, $23,24]$ electrochemical process occures on iron in moist environment. The formed rust are in fact a sort of precipitation with a very fine rust grain and loose distribution. As a result the oxygen and water are easy to approch the metal core and enhance the corrosion.

$$
\begin{aligned}
& \mathrm{Fe} \quad-----\rightarrow \mathrm{Fe}^{+2}+2 \mathrm{e}^{-} \\
& 1 / 2 \mathrm{O}_{2}{ }^{+} \mathrm{H}_{2} \mathrm{O}+2 \mathrm{e}^{-} \rightarrow 2 \mathrm{OH}^{-} \\
& \mathrm{Fe}^{+2}+2 \mathrm{OH}------\rightarrow \mathrm{Fe}(\mathrm{OH})_{2} \\
& \mathrm{Fe}(\mathrm{OH})_{2}+\mathrm{O}_{2}------\rightarrow \mathrm{Fe}_{2} \mathrm{O}_{3} . \mathrm{H} 2 \mathrm{O} \text { Or } 2 \mathrm{FeOOH}
\end{aligned}
$$

It was reported [18] that in the humid environment iron is corroded toY-FeOOH in the beginning ,thenwith the intraction with water and oxygen Y-FeOOH.This coinsides with the experimental results .Analysis of historic data revels that the formation of geothite and lepidocrocite is feavoured in solutions with $\mathrm{pH} 5$ to 7 , whilist $\mathrm{pH}$ values above 8 privilege magnetite formation [29]. In the proportion amount of Goethite and Lepidocrocite was found higher than the magnetite. As bleaching poweder or chlorine dioxide is used in water tretment for disinfection, in chlorine environment water favours the formation of image 


\subsection{Medium Pipe}

The EDS measurement on powder sample ( brown deposit) from the medium pipe identified that iron was the major component element of the scales besides carbon and oxygen. EDS analysis showed that iron was present $36.09 \%$ (atomic percent), Carbon at $10.18 \%$, oxygen at $53.14 \%$ while trace amount of other element such as Silicon and Chlorine (Table-4). The corrosion products are analysed by XRD and the results are shown in Fig.5. Goethite, $\alpha-\mathrm{FeOOH}$, $\mathrm{Fe}_{2} \mathrm{O}_{3} \cdot \mathrm{H}_{2} \mathrm{O}$ (Hydrated ferric oxide), Magnetite, $\mathrm{Fe}_{3} \mathrm{O}_{4}$ and alkaganite, $\mathrm{ß}-\mathrm{FeOOH}, \mathrm{Fe}_{2} \mathrm{O}_{3} \cdot \mathrm{H}_{2} \mathrm{O}$ ( hydrated ferric oxide). It is confirmed from XRD Spectrum of medium pipe sample (Fig.5) that the corrosion product consist of maximum amount of Geothite, probable amount of akaganite and least amount of maganite.

Table-4: Most typical Values of brown deposits of Medium Pipe Sample Obtained from EDS Analysis

\begin{tabular}{|c|c|c|c|c|c|c|c|c|}
\hline Element & C & O & Al & Si & Cl & Fe & Zr & Total \\
\hline Weight \% & 4.08 & 28.89 & -- & 0.55 & -- & 66.97 & --- & 100 \\
\hline Atomic \% & 10.18 & 53.14 & -- & 0.59 & -- & 36.09 & --- & 100 \\
\hline
\end{tabular}

It has been reported [29] that production free energy of goethite at $25^{0}{ }_{\mathrm{C}}$ is-495.748KJmole ${ }^{-1}$, which is less than that of akaganite $-481.7 \mathrm{KJ}$ and maganetite -482 ..Accordingly it can say that goethite is more stabler than maganitite and akaganite in thermodynamics. Magnetite formation is enhanced under the low oxidation codition where as akaganite formation is enhanced in the chloride environment [30]. From EDS data of medium pipe (Table-3), it can be seen that chlorine percent is more in medium pipe which fevours the formation of akaganite than the maganetite.It is reported that chloride ion trapped in the lattice of akaganeite [31]. So induced chloride in the molecular structure of $\mathrm{B}-\mathrm{FeOOH}, \mathrm{Fe}_{2} \mathrm{O}_{3} \cdot \mathrm{H}_{2} \mathrm{O}$ ( akaganeite) is a risk for iron material and chloride element carried by the akaganeite is the main potential trouble. It has been also reported that $ß-\mathrm{FeOOH}$ [33] could act as an accelerating agent and promote electrochemical corrosion process. The $ß-\mathrm{FeOOH}$ works as a reservoir of chloride and the rust layer becomes porous [34].The chloride ions can move through the rust layer and arrive at metal surfaces easily [35]. So akaganeite can be main harmful trouble in water pipes which enhance the further corrosion which may also supply the fevourable condition for the local corrosion to great extent [32]. The SEM mophology of medium pipe sample (Fig.4) shows that goethite was stalactite like on the surface of iron pipe. The grain of goethite was tiny and needle shape this was confirmed in the earlier section (Fig.4). 


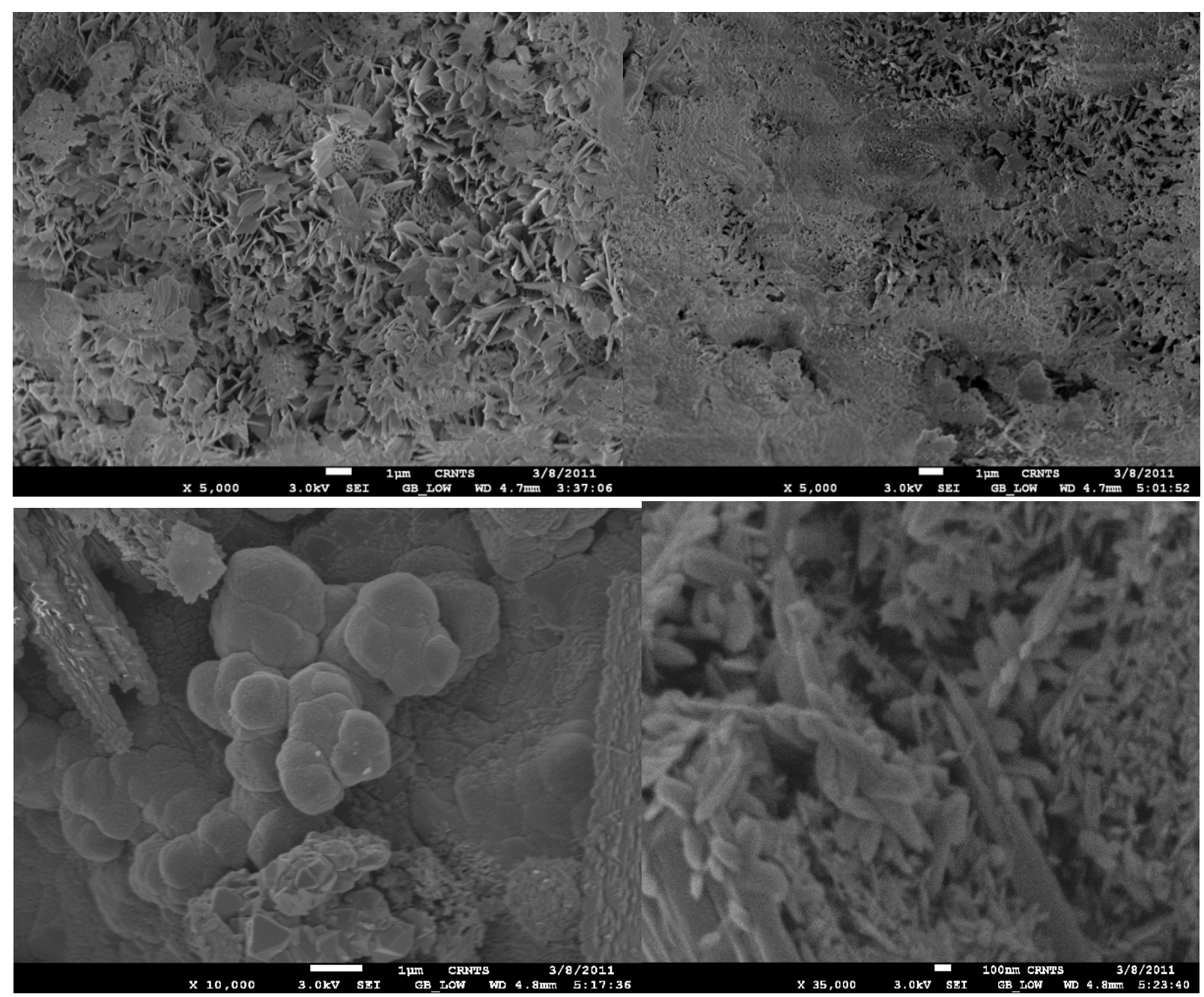

Fig.4: SEM Morphology of Medium Pipe

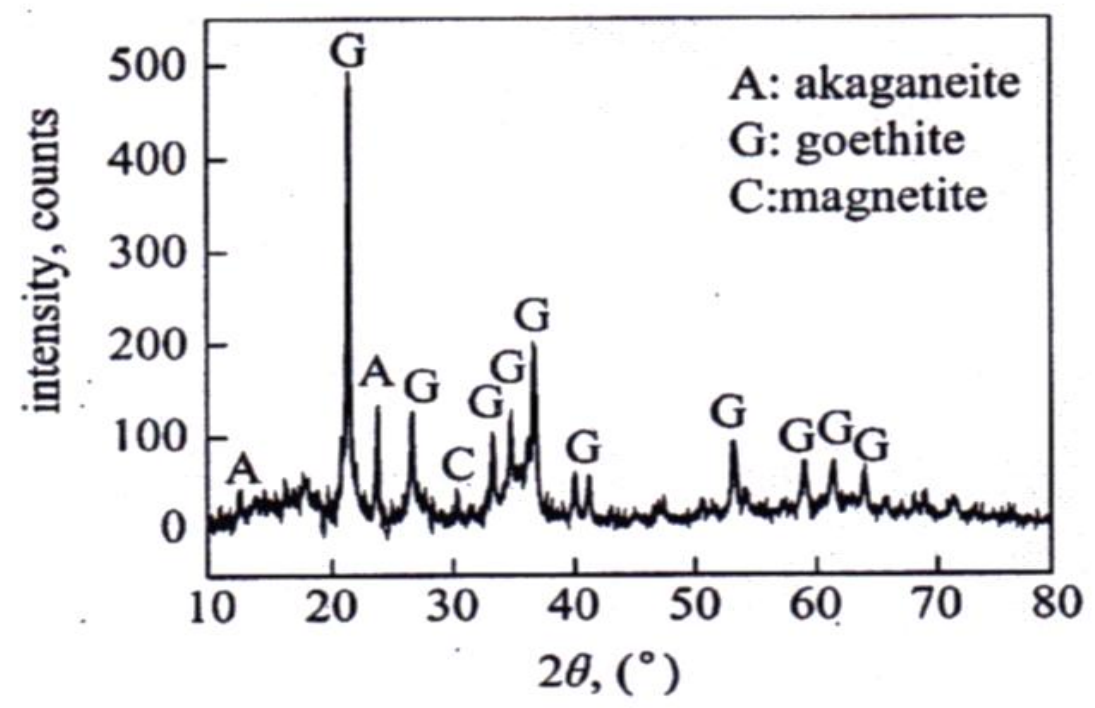

Fig.5: XRD Spectrum of Corrosion Product of Medium Pipe Sample. 


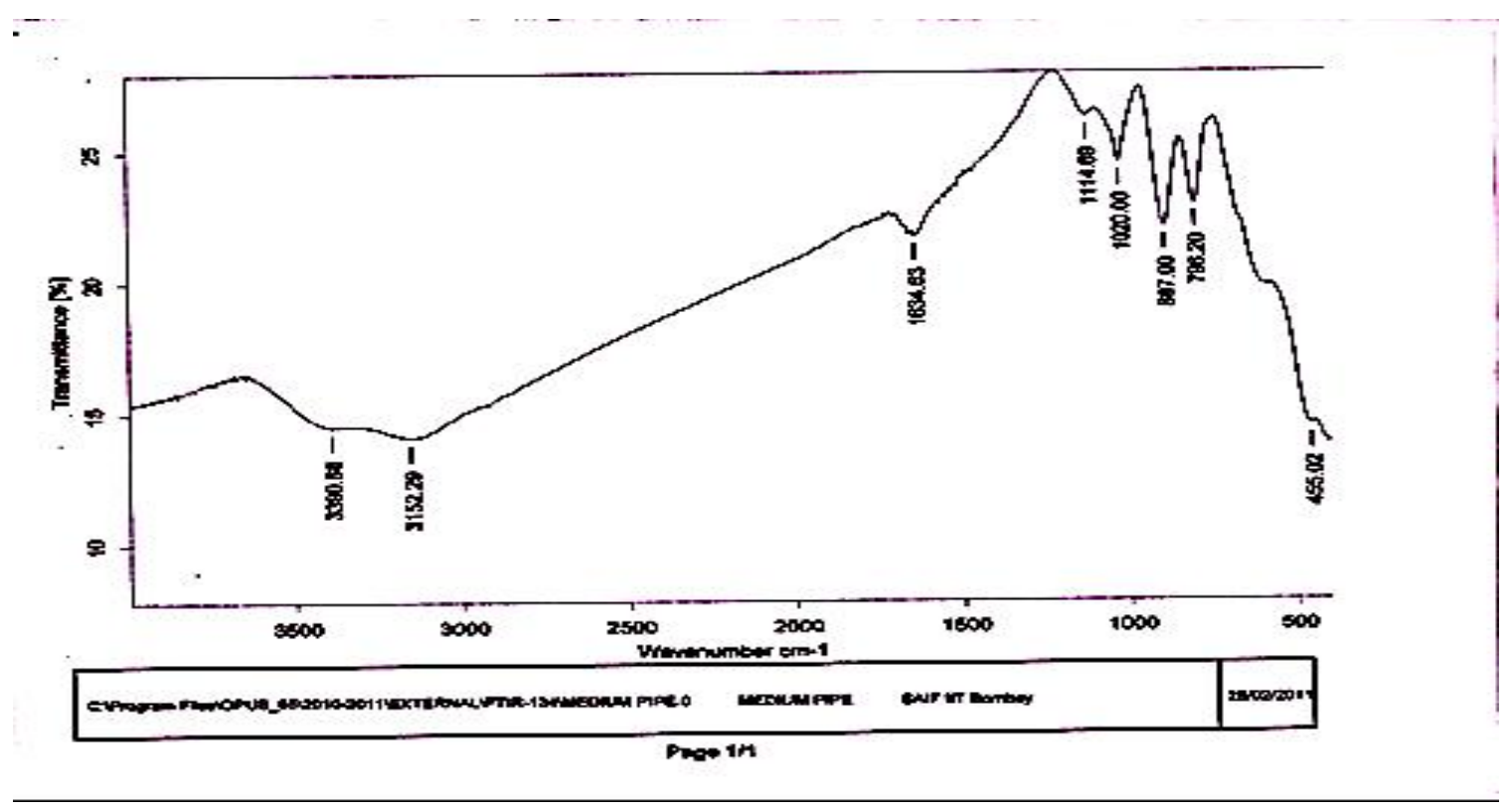

Fig.6: $\quad$ FTIR Spectrum of Medium Pipe Sample

Figure 6 shows the FTIR Spectrum of the medium pipe with a peak at $3390 \mathrm{~cm}^{-1}$ indicating presence of envelope of hydrogen bond surface $\mathrm{OH}$ group. Peak at $3152 \mathrm{~cm}^{-1}$ indicates the Vibration of $\mathrm{OH}$ group in goethite similar result also obtained from XRD Sectrum of medium pipe. Vibration in water shows at $1635 \mathrm{~cm}^{-1}$. Peaks at $1115 \mathrm{~cm}^{-1}$ indicates the presence of complex silicate containing water or hydroxide group vibration whilist peak at $1020 \mathrm{~cm}^{-1}$ indicates the presence of C-C vibrations. Peak at $887 \mathrm{~cm}^{-1}$ and $796 \mathrm{~cm}^{-1}$ vibrations due to presence of C-C and C-Cl. Peak at $455 \mathrm{~cm}^{-1}$. Vibrations of amide species at 1650 and $1550 \mathrm{~cm}^{-1}$ have been reported [26] (Table-4) which as indication of biological material in the sample. However ,the existance of inorganic material generates interference in that region [26] which is the case observed in the present study. Consequntly for cases of deposits composed by mixtures of organic and inorganic matter a better indication of the presence of biofilm.

\subsection{Small Pipe}

The EDS measurement on powder sample ( brown deposit) from the small pipe identified that iron was the major component element of the scales besides carbon and oxygen. EDS analysis showed that iron was present $34.45 \%$ (atomic percent), Carbon at $5.86 \%$, and oxygen at 59.70 $\%$. (See Table-4). The corrosion products are analysed by XRD and the results are shown in Fig.8. Goethite, $\alpha-\mathrm{FeOOH}, \mathrm{Fe}_{2} \mathrm{O}_{3} \cdot \mathrm{H}_{2} \mathrm{O}$ (Hydrated ferric oxide), and Iron Matrix. It is confirmed from XRD Spectrum of small pipe sample (Fig.8) that the corrosion product consist of maximum amount of Geothite,rest of the amount was iron matrix.The composition of grain like substance is already confirmed in previous saction. The SEM mophology of small pipe sample (Fig.7) shows that goethite was stalactite -like on the surface of iron pipe .The grain of goethite 
was tiny and needle shape this was confirmed in the earlier section (Fig7). Lot of cavities or gaps are seen and iron matrix is exposed on local surface.

Table-5: Result of the analysis of the IR Spectra of Medium pipe Sample

\begin{tabular}{|c|l|l|l|}
\hline $\begin{array}{c}\text { Sample } \\
\text { (Spectrum) }\end{array}$ & \multicolumn{1}{|c|}{$\begin{array}{c}\text { Absorption } \\
\text { Frequency } \mathbf{( c m}^{-\mathbf{1}} \mathbf{)}\end{array}$} & \multicolumn{1}{|c|}{$\begin{array}{c}\text { Related Compounds, Groups or } \\
\text { Vibration }\end{array}$} & Reference \\
\hline \multirow{5}{*}{ Small Pipe } & 3409 & 0H phenolic & 21 \\
\cline { 2 - 4 } & 3150 & C-H aromatic & 22 \\
\cline { 2 - 4 } & $2922 \& 2853$ & C-H aliphatic & 22 \\
\cline { 2 - 4 } & 1635 & C=C & 22 \\
\cline { 2 - 4 } & 1119 & C-O & 22 \\
\cline { 2 - 4 } & 1020 & C-C \& C-O & 19 \\
\cline { 2 - 4 } & 886,796 & Goethite & 22 \\
\hline
\end{tabular}

Table-6: Most typical Values of brown deposits of Small Pipe Sample Obtained from EDS Analysis.

\begin{tabular}{|c|c|c|c|c|c|c|c|c|}
\hline Element & C & O & Al & Si & Cl & Fe & Zr & Total \\
\hline Weight \% & 2.38 & 32.38 & & -- & -- & 65.23 & -- & 100 \\
\hline Atomic \% & 5.86 & 59.70 & & -- & -- & 34.45 & -- & 100 \\
\hline
\end{tabular}

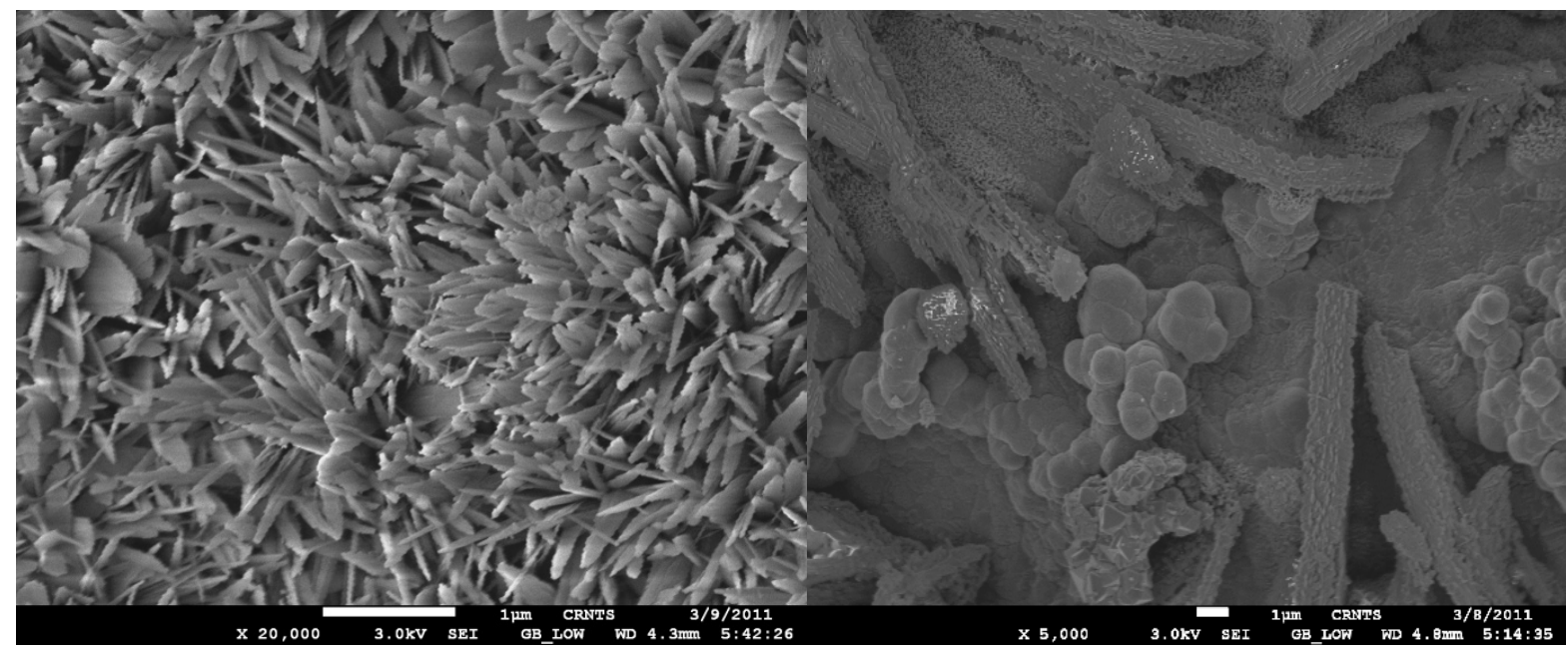




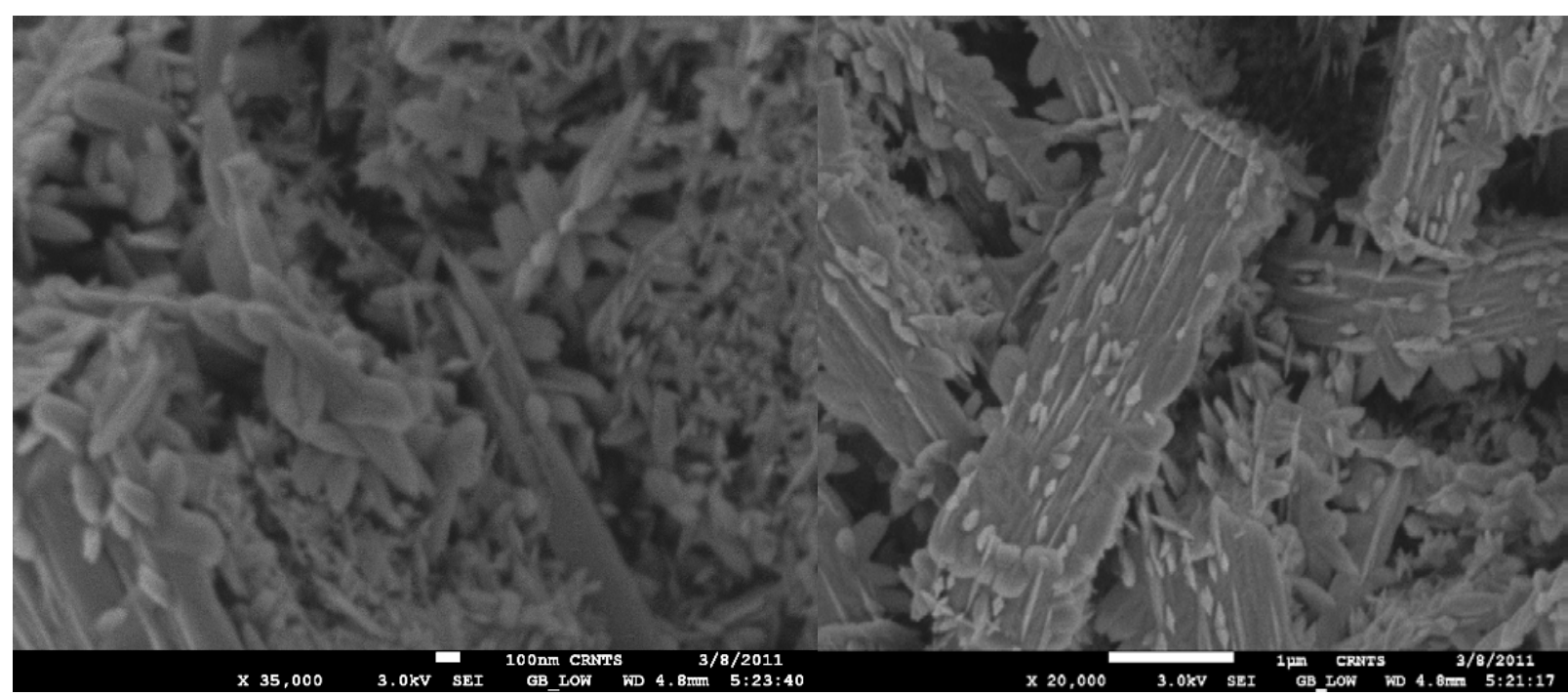

Fig.7: SEM Morphology of Small Pipe

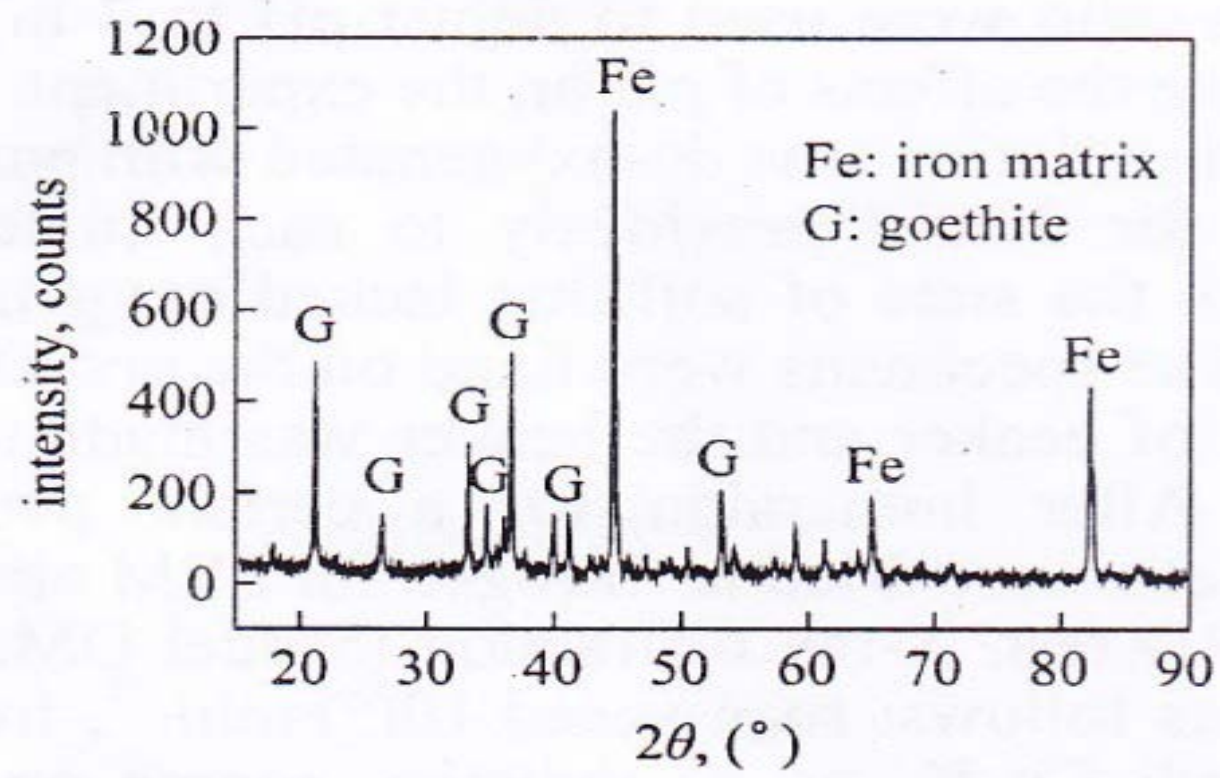

Fig.8: XRD Spectrum of Corrosion Product of Small Pipe Sample.

Fig.9 shows the FTIR Spectrum of the small pipe with a peak at $3409 \mathrm{~cm}^{-1}$ indicating presence phenolic $\mathrm{OH}$ group. Peak at $3150 \mathrm{~cm}^{-1}$ indicates the presence of $\mathrm{C}-\mathrm{H}$ vibration in $\mathrm{CH}_{3}$ or $\mathrm{CH}_{2}$. group. Peaks at 886 and 796 indicates the presence of goethite, similar result also obtained from XRD Sectrum of small pipe. Vibrations due to presence of C-H aliphatic group obsereved at $2922 \mathrm{~cm}^{-1}$ and $2833 \mathrm{~cm}^{-1}$. Another peak at $1635 \mathrm{~cm}^{-1}$.indicates the presence of $\mathrm{C}=\mathrm{C}$ vibrations. Besides the presence of $\mathrm{C}=\mathrm{O}$ stretch was noticed at $1119 \mathrm{~cm}^{-1}$ and $\mathrm{C}-\mathrm{C}$ alphatic stretch seen at $1020 \mathrm{~cm}^{-1}$. Presence of organic functional group indicates the adsorption of biofilm in water pipe [16,27]. It has been explained in the earlier section of medium pipe that the 
existance of inorganic material generates interference in that region [26] which is the case observed in the samll pipe. Consequntly for cases of deposits composed by mixtures of organic and inorganic matter a better indication of the presence of biofilm [16,27]

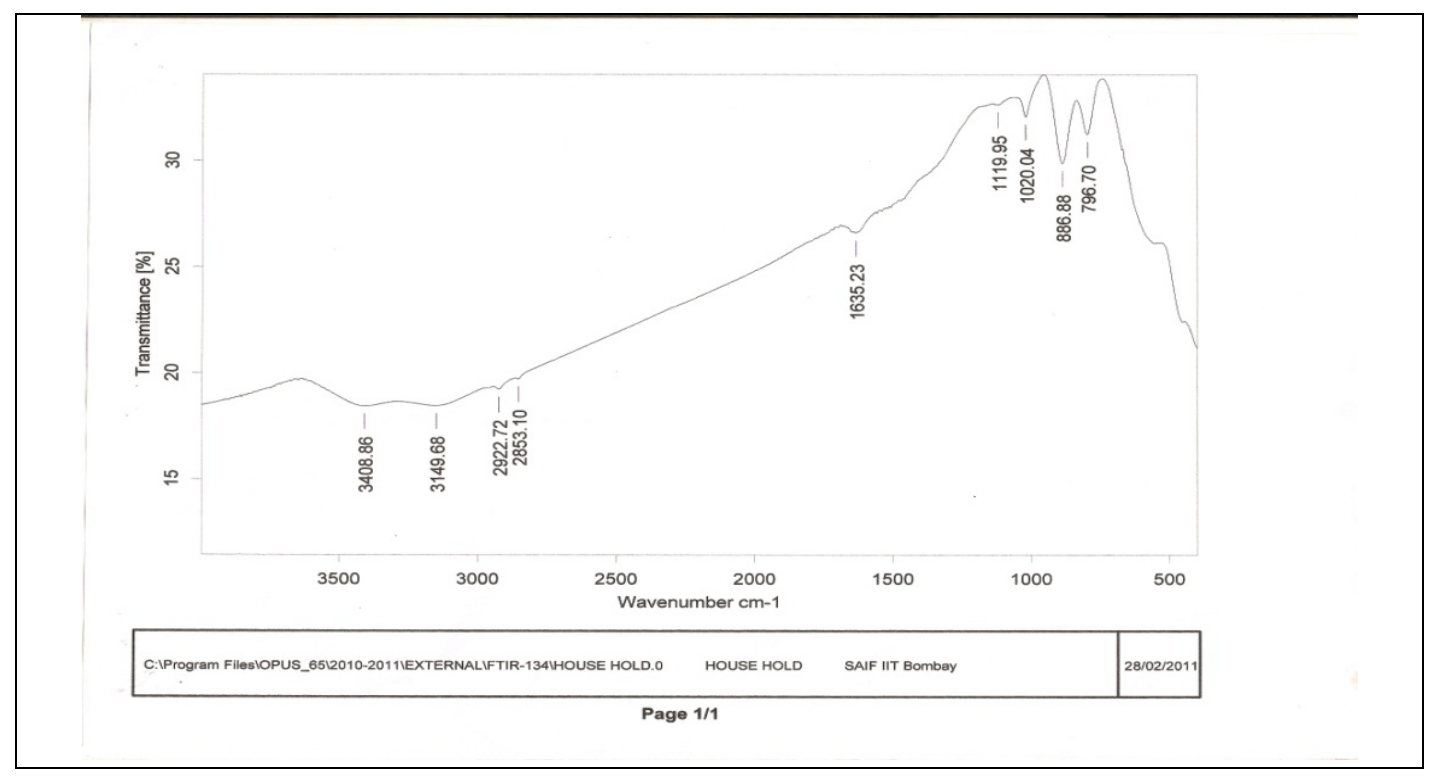

Fig.9: $\quad$ FTIR Spectrum of Small Pipe Sample

Table-7: Result of the analysis of the IR Spectra of Small pipe Sample

\begin{tabular}{|c|l|l|c|}
\hline $\begin{array}{c}\text { Sample } \\
\text { (Spectrum) }\end{array}$ & \multicolumn{1}{|c|}{$\begin{array}{c}\text { Absorption } \\
\left.\text { Frequency } \mathbf{( c m}^{-\mathbf{1}}\right)\end{array}$} & $\begin{array}{c}\text { Related Compounds , } \\
\text { Groups or Vibration }\end{array}$ & Reference \\
\hline & 3409 & OH phenolic & 21 \\
\cline { 2 - 4 } & 3150 & C-H aromatic & 22 \\
\cline { 2 - 4 } Small Pipe & $2922 \& 2853$ & C-H aliphatic & 22 \\
\cline { 2 - 4 } & 1635 & C=C & 22 \\
\cline { 2 - 4 } & 1119 & C-O & 22 \\
\cline { 2 - 4 } & 1020 & C-C \& C-O & 22 \\
\cline { 2 - 4 } & 886,796 & Goethite & 19 \\
\hline
\end{tabular}

\section{CONCLUSION}

The analysis of deposit in water distribution pipes of Ulhasnagar city revels that the predominance of brown deposits. Organic matter was also found to present. Brown deposits in big pipe sample contain aluminosilicates compounds. Tubercles are formed by electrochemical 
and microbiological activity. They are composed mainly of goethite, Lepidocrocite, hematite and magnetite. Similarly medium pipe composed of Goethite, Akaganite and magnetite while small pipe sample composed of Goethite and iron matrix. FTIR analysis could be used as indication of the formation of organic material in the sample and therefore, as indicator of the presence of biofilm. An interference of spectra has been observed due to mixture of organic and inorganic mixture in the sample.

\section{ACKNOWLEDGEMENTS}

The Authors wish to thank Ulhasnagar Municipal Corporation Authorities for providing pipe samples and other important information and S.A.I.F. IIT Mumbai. The Authors also thankful to Dr. Bhatt, Scientist, BTRA Mumbai and Dr. S.R.Mirgane, Associate Professor, J.E.S.College, Jalna for their valuable suggestions and guidance.

\section{REFERENCES}

[1] Heryong Jung, Unij Kim, Gyutae Seo, Hyundong Lee and Chunsik Lee, (2009) Environmental Engineering Research, Vol.14, No.3, 195-199.

[2] T.S. Rao, T.N. Sairam, B. Vishwanathan and K.V.K. Nair, (2000) Corrosion Science, Vol.42, No.8, 147-131.

[3] P. Sarin, V. L. Snoeyink, J. Bebee, W. M. Kriven and J. A. Clement, (2001) Water Research. Vol. 35, no. 12, 2961-2969.

[4] Benjamin M.M.Sontheimer H. and Leroy P.(1996) Corrosion of Iron and Steel in Internal Corrosion of Water Distribution Systems,Cooperative Research Report,AWWA Research Foundation,Denver Co.

[5] Lechevallier M.W.Lowry C.D.,Lee R.G. and Gibbon D.L.(1993) Journal of AWWA,85(7), 111-123.

[6] S,A, Imran, J.D. Dietz, G. Mutoti, J.S. Taylor, A.A. Randall and C.D. Cooper, (2005) Journal AWWA, Vol.97, No.9, 93-100.

[7] Zhe Zhang Janet E.Stout Victor L. Yu, Radisav Vidic, (2008) Water Research,Vol.42,129136.

[8] Aieta E.M. Berg D.J.A (1986) J.AWWA, Vol.78(6), 62-72.

[9] O.M. Zachus, M.J. Lehtola, L.K. Korhonen and P.J. Martikainen, (2001) Water Research, Vol.35, No.7, 1757-1765.

[10] M.W.Lechevallier,T.W.Babcock and R.G. (1987) Applied and Environmental Biology,Vol.53,No.12,2714-2724.

[11] Ravin K.P.Jain A. and Loeppert R.H.,(1998) Environ.Sci.Technology,32(32) 3, 344-349.

[12] ESPA Arsenic Guidelines

[13] Larson and Skold R.V. (1957) J.AWWA,Vol.49,1294-1301. 
[14] Viraghavan T; Subramanian K.S.Rao and Rao B.V. (1996) Journal Environmental Science Health Association 31(8),2005-2016.

[15] Felix Excheverria ,Juan G. Castano, Carlos Arroyave, Gustrao Penuela Auxilo Ramirez and Jordi Morato, J.AWWA (2009) Vol.17 No.2,275-281.

[16] Gauthier, J.M. Portal, Y. Yvon, C Rosin, J.C. Block, V. Lahoussine, S. Benabdallah, J. Cavard, D. Gatel and S. Fass, (2001) Water Science and Technology, Water Supply, Vol.1, No.4, PP 89-94.

[17] Geldreich E.E. Internal Corrosion and Deposition Control in Water Quality and Treatment , McGraw Hill, New York,1990.

[18] Wang Zise, Xu Chunchun, CAO Xia, and Xu Ben, (2007). Chin.JournalChem.Eng;15(3), 433-438

[19] H. Komada. Technical bulletin 1985-1E”. Research Program Service, Minister of Supply and Services, pp. 198. Ottawa, Canada.

[20] E. Contreras, E. Leal and M. I. Martínez. (2004) RevistaTécnica de la Facultad de Ingeniería. Universidad del Zulia. Vol. $27 \mathrm{~N}^{\circ}$ 2,114-122.

[21] S. Music, G. P. Santana, G. Smit and V.K. Garg. (1998) Journal of Alloys and Compounds.Vol. 278 No. 1, 291-301.

[22] A.I.J. Mendham, R.C. Denney, J.D. Barnes, and M. Thomas, (2000) Vogel's Quantitative Chemical Analysis,6 ${ }^{\text {th }}$ Edition ,720-744.

[23] Sarin, P. Snoeyink,V.L;B.L. Lytle,D.A; (2004) Journal Environmental Engineering , Vol.130 (4), 2004, 365-373.

[24] Tang Z,; Hong, S; Xiao W, Taylor, J; (2003), Corrosion Science, Vol.48(2), 322-342.

[25] J.Lin and B.A.W. (1998) Water Research,Vol.32,No.4, 1019-1026.

[26] L.I. Sly, M.C. Hodgkinson and V. Arunapairojana, (1990) Applied an Environmental Microbiology,Vol.56,No.3,628-639.

[27] V.Gauthier, B.Geanard, J.M.Portal, J.C.Block and D.Gatel, (1999) Water Research, Vol.33, No.4, 1014-1026.

[28] S.Music,G.P.Santana,G.Smit and V.K.Garg, Fe Mossbauer, (1998) Journal of Alloys and Compounds,Vol.278.No.1, 291-301.

[29] Zhu,H.F. Zhou,H. Cai,L.K., (2002) Conserv.Archaeol;14(Suppl.),52-62.

[30] L.A.Raman ,(2006), Water Research,Vol.No.13,2493-2502.

[31] S.T. Wang, S.W. Yang, K.W. Gao and X.L. He( 2008) Acta Metall. Sin.(Engl. Lett.)Vol.21 No.6,425-436 .

[32] T. Nishimura, H. Katayama, K. Noda and T. Kodama, (2009) Corrosion 56(9), 935.

[33] ISO-DIS 8565.2 Metal and Alloys-Atmospheric Corrosion Testing-General Requirement for Field Test (Geneva, Switzarland: ISO,1991.

[34] T.E. Graedel and R.P. Frankenthal, J. Electrochemica. Soc. 137(8) (1990) 2385. 